\title{
TCOM \\ COVID-19 infections on international celebrities: self presentation and tweeting down pandemic awareness
}

\section{Wishes Tendayi Mututwa and Trust Matsilele}

Abstract

Keywords

DOI

Introduction
The novel coronavirus (COVID-19) which was first reported in China's Wuhan province in December 2019 became a global pandemic within a few months. The exponential rise in COVID-19 cases globally was accompanied by a spike in misinformation about the pandemic, particularly on social media. Employing Social Network Theory as a lens, this qualitative study explores how selected international celebrities appropriated their Twitter micro-blogging pages to announce their COVID-19 infection to the world. The study finds that these celebrities can take advantage of their huge social media following to counter disinfodemic and promote awareness about health pandemics.

Health communication; Popularization of science and technology; Science and media

https://doi.org/10.22323/2.19050209

Submitted: 29th June 2020

Accepted: 25th August 2020

Published: 30th September 2020
The coronavirus disease (COVID-19) is a highly transmittable and pathogenic viral infection. This disease is caused by severe acute respiratory syndrome, coronavirus 2 (SARS-CoV-2) which was first reported in Wuhan, China, and then spread to 136 countries within three months. As of August 14 2020, 213 countries and territories around the world have reported a total of 21,102,920 confirmed cases of COVID-19, and a death toll of 758,036 deaths [Worldometer, 2020]. While the intermediate source of origin and transfer to humans is still under investigation, the rapid human to human transfer has been confirmed widely [World Health Organization, 2020]. Within the early stages of the pandemic, there was a surge in misleading rumours and conspiracy theories about the origin and cure of COVID-19, coupled with fearmongering, racism and stigma, mainly on social media [Depoux et al., 2020]. Epicentres of COVID-19 were often targeted, leading to widespread distrust and outburst of racism. For instance, Chinese restaurants, Chinese tourists and goods from Asia were the first victims of viral racism [Depoux et al., 2020].

The proliferation of disinfodemic and misinformation about COVID-19 can generate hefty deleterious consequences on health initiatives. According to Posetti 
and Bontcheva [2020], disinfodemic refers to falsehoods fuelling the pandemic and its impacts. Misinformation is closely related to the culture of rumours. As Qazvinian et al. [2011, p. 1589] intimate, a "rumour is commonly defined as a statement whose true value is unverifiable". Qazvinian et al. [2011, p. 1589] further opine that "rumours may spread misinformation (false information) or disinformation (deliberately false information) on a network of people." Conceptually, misinformation can therefore be referred simply as false information while disinformation has to do with the deliberateness through which false information is shared. There is no convincing literature that associates celebrities with COVID-19 disinfodemic. However, they have been identified as among the key distributers of misinformation about the pandemic [Brennen et al., 2020]. Misinformation makes it hard for people to find trustworthy sources and reliable guidance when they need it. The central question to this study is, what role did the international celebrities play to mitigate effects of COVID-19 misinformation? If not addressed urgently, misinformation about a pandemic has a potential to negate official health initiatives.

This study builds on the recommendations by Depoux et al. [2020] that social media can and should be harnessed to support public health response. Leung and Cheng [2016] argue that celebrities can play a pivotal role in galvanising heath awareness, utilising the immense social media clout at their disposal. The newspaper, Vulture [2020] has documented celebrities who appropriated social media to announce their COVID-19 infection, reflecting the potential of celebrities to amplify official health communication. Extant research reveals that when information is vivid and easy to understand, we are more likely to recall it. People are more likely to believe a claim when it is a real life experience backed by a photo or video [Newman et al., 2020]. Twitter has emerged as a robust platform for engagement, allowing messages to reach a wider audience within a short space of time. This advantage carries an inherent danger, especially when appropriated for undermining positive policy initiatives. The advantage of Twitter lies in its strong network. A research by Anger and Kittl [2011] reflects that a large part of Twitter users retweet and amplify content which is considered as entertaining, useful or breaking news. In this study, we have employed Social Network Theory to show how a Twitter post can easily spread across the network, particularly when the post is from an influential person or arouses public interest. The micro-blogging platform allows a user to express agreement and liking with the amplification of content on the one hand; on the other hand, he wishes to establish himself as an information hub and gain social influence [Anger and Kittl, 2011]. There is limited research which offers convincing information on voluntary participation by celebrities to fight a health emergency through their social media platforms [Ngewa and Kuriansky, 2016; Sonke and Pesata, 2015]. Building on these few seminal cases, this study explores the role celebrities can play in countering disinfodemic through announcing their COVID-19 infection on Twitter.

\section{Celebrities as influencers of public opinion}

There are three types of celebrity: ascribed celebrity, traditional celebrity and celetoid. Ascribed celebrity is linked to the bloodline whereby hereditary titled individuals such as kings, queens, emperors, duchesses and so forth command influence and respect within the social hierarchy [Rojek, 2001]. Traditional 
celebrities are people who have gained public recognition because of their professional talent [Khamis, Ang and Welling, 2017]. Celetoids are individuals who gain a huge burst of fame [Rojek, 2001]. The role of traditional celebrities is evolving with the developments in digital technologies. Zak and Hasprova [2020] opine that traditional celebrities have become online influencers, appropriating online spaces to communicate and engage with online users. Montoya and Vandehey [2009] understand an influencer in terms of a set of external personal perceptions that encapsulate the expectations, promises and experiences that an individual displays to others. These influencers are often people who grow their popularity socially or economically and individual members of society look up to them for certain decisions or behaviours within their areas of influence. They share personal information, news, photos and videos which can influence the opinions and attitudes of others, popularly known as influencer marketing. Info tech has become the major driver of business. Therefore, influencer marketing can be said to be one of the fastest growing tools in reaching new consumers with the help of online media [Zak and Hasprova, 2020]. Celebrities have also played an important role in mediating health communication, often contracted by health organisations. In Germany, communication of health related topics such as nutrition and exercise has been amplified by celebrities [Zak and Hasprova, 2020]. Heldman, Schindelar and Weaver [2013] note that there is so much debate on how social media can be harnessed to best achieve public health outcomes.

A study by Korda and Itani [2013] has examined the effectiveness and implications of using social media and other digital media in health promotion and disease prevention endeavours, and there has been less compelling evidence of its efficacy in impacting public health. Heldman, Schindelar and Weaver [2013] acknowledge that many health organizations have established a social media presence but the role of social media engagement in advancing public health communication work at the organisational level is infrequently discussed. Researchers have established that there is need to harness the participatory culture of social media if it is to be fully utilised in health communication [Heldman, Schindelar and Weaver, 2013; Neiger et al., 2013]. The COVID-19 pandemic has been described as a historical chapter which has resulted in disinfodemic, particularly on social media. Communication about the devastating and global impact of the pandemic has been so vital in order to slow down infections. During the initial stages of the COVID-19 pandemic, there was widespread rumour and conspiracy theories around the virus.

In Africa, it was widely rumoured that Africans were immune to COVID-19. Politicians were at times at the forefront of the misinformation. For instance, Zimbabwe's Minister of Defence, Oppah Muchinguri claimed that the coronavirus was God's punishment on the Americans for imposing economic sanctions on Zimbabwe [Chris, 2020]. In Burundi, the then late president Pierre Nkurunzinza claimed the pandemic was transmitted by air and 'God has cleared the coronavirus from Burundi skies' [Donmez, 2020]. Nkurunzinza allegedly died of COVID-19 on 8 June 2020 and his wife was airlifted to Kenya for treatment of COVID-19 symptoms [Bearak, 2020]. In U.S.A., president Donald Trump dismissed the severity of the virus until too late and African Americans spread rumour that blacks were resistant to the virus because of their melanin. However, the official statistics later proved that claim to be misleading. According to AMP Research Lab [2020], as at 12 August 2020, the overall COVID-19 mortality rate for Black Americans was 3.7 times as high as the rate for White Americans and Asians and 
2.2 times as high as the Latino rate. Therefore, disinfodemic on social media propagated a false belief that there were certain people who could be safe from infection. When celebrities spoke about their infections, they acted as agents to demystify the false narratives about COVID-19. Heldman, Schindelar and Weaver [2013] argue that social media engagement is fast emerging as a way to complement and support the existing evidence and best practices from the community engagement and community building perspectives. Twitter has developed as a tool of persuasion and propaganda in political contexts and situations of crisis to such an extent that it has given rise to a rhetoric of persuasion and propaganda discourse models [Rueda and Helfrich, 2014]. It is in this context that celebrities who tested positive for COVID-19 took to Twitter to spread information about the reality of the pandemic.

When cases of COVID-19 infections and mortality began to rise exponentially in different countries, the world struggled to contain the flow of fake news surrounding COVID-19, even as it pushed back against the pandemic with lockdowns and other emergency measures [Banerjee, 2020]. The barriers to entering health information marketplace means that those who have access and power are able to determine almost single-handedly what is considered authorized, truthful health information [Waisbord, 2020]. Misinformation is disastrous and sows confusion about life-saving personal and policy choices [Posetti and Bontcheva, 2020]. Researchers have observed that disinformation has corrosive effect of creating misinformed citizens [Mare, 2018; Mare and Matsilele, 2020; Mutsvairo and Bebawi, 2019]. Since the outbreak of the pandemic in December 2019, at least 130 celebrities worldwide, among them politicians, entertainers and athletes had tested positive to COVID-19 by August 2020 [Vulture, 2020]. Visual self-presentation on social media by celebrities who had tested positive for COVID-19 could be understood as an attempt to raise awareness and counter disinfodemic about the pandemic. The majority of them used social media, particularly, Instagram, Facebook and Twitter to announce their condition and encourage their fans to practise social distancing and healthy habits that safeguards them from COVID-19 [Scott and Wray, 2020]. Since influencers can exhibit characteristics of credibility, persistence in convincing others, and drive conversations so that others can take of the topic or idea and show support, testimonies by infected celebrities have the potential to counter misinformation, proving that COVID-19 is a reality and no one is immune to the pandemic [Biran et al., 2012]. Cohen, cited in a research by West Virginia University [2020] notes that these announcements may help make people understand how far-reaching the virus is or they make people think celebrities are just like us.

\section{Twitter and pandemic awareness: lessons from the Ebola epidemic}

The Ebola outbreak was officially declared in March 2014 in Guinea, after which the disease was transmitted through human movement to Sierra Leone, Liberia, Nigeria, the U.S.A., European Union countries, Senegal and Mali [World Health Organization, 2015]. WHO declared the Ebola virus dieses (EVD) a global health epidemic on 8 August 2014 [Tran and Lee, 2016]. Twitter amplified awareness about the epidemic [Odlum and Yoon, 2015]. On 24 July 2014, a few days before the Ebola virus was declared a global health emergency, tweets mentioning the EVD reached 1,502,743 Twitter users and on July 26, with the announcement of the EVD 
infection of an American physician, there was a 644-fold increase in disseminated tweets to 967,404,925 [Odlum and Yoon, 2015]. A study by Essoungou [2010] has revealed that Africans are participating in global conversations more and more. For example, Trevor Noah, a South Africa stand-up comedian has used his social media popularity to speak about topical issues that include the COVID-19 pandemic and \#Blacklivesmatter, an American civil rights movement that gained global popularity after the murder of George Floyd by Minneapolis police officers on 25 May 2020. The technological boom has offered Africans an opportunity to own mobile phones and laptops which allow them to spend most of their time on social networking sites such as Facebook, Twitter and Instagram. After the official announcement of the first case in Nigeria, an increase in tweet frequency from cities was identified. Odlum and Yoon [2015] note that tweets steadily increased (6-fold in posted tweets and 20-fold in disseminated tweets) from July 24-31, the day of the CDC official Nigeria case report. In an article, 'How twitter may have helped Nigeria contain Ebola', Odlum and Yoon [2015] establish how local media personalities became instrumental in sharing accurate information about the pandemic. A dentist, Lawal Bakare, emerged as a pivotal influencer as he popularized an Ebola awareness campaign on Twitter called @EbolaAlert [Odlum and Yoon, 2015]. His message was widely received because he shared information through links to its original form, therefore dispelling the fear of misinformation associated with social media. Researchers have found that personal accounts of celebrities such as Barak Obama and Bill Gates triggered more Ebola retweets than disseminators and common users [Liang et al., 2019].

While social media has been widely credited for broadening the discursive platform around the Ebola virus, concerns have been raised about abuse of the same to peddle misinformation, blame, rumour, fear among other vices [Jin et al., 2014]. One of the widely tweeted rumours about the spread of the virus was the snake rumour. Twitter users rumoured that the Ebola virus crossed the border from Guinea to Sierra Leone via a snake in a bag. Oyeyemi, Gabarron and Wynn [2014] established that in Guinea, Liberia and Nigeria, most tweets and retweets contained misinformation, and this misinformation had a much larger potential reach than correct information. In the United States, future president Donald Trump tweeted about Ebola's threat to the Americans [Salek and Cole, 2018]. While the message could have been useful in Ebola awareness, Salek and Cole [2018] argue that social media allowed influencers like Trump to constitute an apocalyptic counterpublic where unsubstantiated claims increased public panic in the United States. A research by Brennen et al. [2020] has found that celebrities have played a key role in spreading COVID-19 misinformation on social media, thus reflecting the pitfalls of social media and celebrity influence in mediating health pandemics.

In mediating their coronavirus infection, some celebrities may have preferred to use Twitter to other social media platforms not only because of its increasing popularity but also its limited level of access to the user's personal information [Stever and Lawson, 2013]. Recent statistics reveals that there are 386 million Twitter users globally and 152 million daily users in 2020 [Clement, 2020]. For celebrities who use Twitter, the dialogue is serious, meaningful, and appears to have impact for those participating [Stever and Lawson, 2013]. One of the advantages of Twitter over other social media platforms is the emphasis on key terms used in a tweet via hashtags that enable users to collect similar tweets and their subjects according to the frequency of use and relevance. This facility allows 
users to quickly and easily have insight into a wide range of tweets that are connected with specific topics [Bruns, Highfield and Lind, 2012, p. 23]. Hashtags also allow users to virtually gather and discuss trending topics and events [Bruns, Highfield and Lind, 2012, p. 24]. There is abundant research which focus on the appropriation of Twitter by celebrities to create an online image so that their audience is swayed towards a particular brand or lifestyle [Rettberg, 2017]. Very little research has been done to explore the role that celebrities can voluntarily play, capitalising on their huge following to spread health awareness during times of pandemics. This paper argues that the scope of self-presentation on social media should not just be limited to advertising, lifestyle and self -imaging but should be extended to its ability to be used to address societal challenges.

\section{Social network theory and Twitter}

This study is informed by Social Network Theory to explore how celebrities used their Twitter microblogging sites to announce their COVID-19 infection to their followers across the world. Claywell [2016] defines Social Network Theory as the study of how people, organizations or groups interact with others inside their network. Networks can be understood as neighbourhoods because they are comprised of the actors (nodes) and the relationships (ties) between those actors [Pataraia et al., 2014]. These actors, referred to as nodes, can be individuals, organizations or companies and are the smallest single unit inside a network. To understand the efficacy of Twitter, it is important to highlight that a network consists of a set of relationships [Kadushin, 2004]. In this paper, we were concerned with the interactions between each of the members of the network on twitter. In addressing that, these questions were pertinent: Why do the individuals interact? how do they interact and what is the level of closeness or connectedness?

For this study, we considered the types of social networks: egocentric, socio-centric and open-systems then settled for one that best suited our research focus. In socio-centric network, members of the network are usually known or are easily determined because the focus is usually on a priori defined closed network [Scott, 2000]. The open-system network has no clearly defined boundaries. As Kadushin [2012] notes, a few elite class and a chain of influencers or a particular decision are found in this network, making it difficult to study. As such, data collection will require collecting enumerating all network members and administering saturation surveys to all network members. Lastly, egocentric network designs target the actor, ego and the relationship between the ego and the actors within their social network [Scott, 2000]. Out of the three types, this study employed the egocentric network. This is connected with a single node or individual, for example, all of a Twitter user's followers on Twitter [Claywell, 2016]. Each of the types can be reduced to either a strong tie or a weak tie. Strong ties are close enough to you that you probably have some personal details about these people, whereas weak ties would be surprised if you called one of them [Kadushin, 2004]. However, it does not mean the closer the tie the more valuable it is. Research reveals that the weak ties in a network are, in some ways, more valuable [Granovetter, 1973]. Granovetter [1973] further argues that weak ties play a seminal role in building trust among a social network of loosely affiliated members which is essential for rallying behind a cause such as COVID-19 awareness. Applying this understanding to a celebrity's Twitter network, people across the world are members of the network but not all 
individuals are connected with the same degree of closeness. It's these varying degrees of closeness, or connectedness that determine the value of that node to the network [Kadushin, 2004]. As Anger and Kittl [2011] argue, apart from number of followers a user has, the number of retweets and mentions also reflects the potential reach of a tweet. A single tweet has the potential to reach millions of Twitter users, all connected within the network.

\section{Operationalisation of the study}

This study selected Twitter accounts of international celebrities globally who publicly revealed they had tested positive for COVID-19. Data was gathered between March 1 and 31 July 2020. From a global perspective, a sample of 100 international celebrities who tested positive for COVID-19 was selected. Out of these, our sample was narrowed down to those who used Twitter to announce their COVID-19 positive test results. We established that 25 celebrities from our sample used Twitter. We therefore, purposively selected 15 celebrity accounts, guided by the research's global focus. It should be noted that the distribution of celebrities was not even across the continents because some countries experienced more COVID-19 cases than others, therefore influencing the infection rates.

Qualitative Content Analysis (QCA) was used to analyse data. For the purposes of the current study, the QCA method is defined as "the systematic reduction of content, analysed with special attention to the context in which it was created, to identify themes and extract meaningful interpretations of the data" [Roller and Lavrakas, 2015, p. 232]. Therefore, both a tweet and the responses to that message are all parts of a construction of a social reality within the online community. Celebrities who tested positive for COVID-19 took to their Twitter sites to share the new reality with their online community and this study focuses on their initial tweet(s) revealing their COVID-19 infection. In QCA, content embraces all appropriate data sources beyond the text such as images, videos, audio, graphics and symbols [Kuckartz, 2014]. Concept-driven coding of data was done manually on celebrities' initial tweet(s) on their COVID-19 infection. Coding is the process of labelling and organizing qualitative data to identify different themes and relationships between them [Medelyan, 2019]. Medelyan [2019] defines concept-driven coding, also known as deductive coding as a process where you start with predefined set of codes, then assign those codes into new qualitative data. Coding represents the gritty craftsmanship that enables artful and creative interpretation and analysis of the data [Linneberg and Korsgaard, 2019]. Data was analysed, coded then the codes were categorized with coding frames. The process was carried out with the objectives of the study in mind and this helped eliminate texts that were not aligned to the research objectives. 
Table 1. Celebrity tweets recorded between 1 March and 31 July 2020.

\begin{tabular}{|c|c|c|c|c|c|c|}
\hline $\begin{array}{l}\text { Celebrity } \\
\text { account }\end{array}$ & $\begin{array}{l}\text { No. of } \\
\text { followers }\end{array}$ & Tweet & $\begin{array}{l}\text { No. of } \\
\text { comments }\end{array}$ & $\begin{array}{l}\text { No. of } \\
\text { retweets }\end{array}$ & $\begin{array}{l}\text { No. of } \\
\text { likes }\end{array}$ & $\begin{array}{l}\text { No. of } \\
\text { views }\end{array}$ \\
\hline $\begin{array}{l}\text { Tom Hanks } \\
@ \text { tomhanks } \\
12 \text { March } \\
\text { American actor } \\
\text { and filmmaker. }\end{array}$ & $16.7 \mathrm{~m}$ & $\begin{array}{l}\text { Hello folks. Rita and I } \\
\text { are down here in Aus- } \\
\text { tralia. We felt a bit } \\
\text { tired, like we had colds, } \\
\text { and some body aches. } \\
\text { Rita had some chills that } \\
\text { came and went. Slight } \\
\text { fever too. We were } \\
\text { tested for Corona virus } \\
\text { and were found to be } \\
\text { positive }\end{array}$ & 46,000 & 220,000 & 100,000 & $\begin{array}{l}\text { No } \\
\text { video }\end{array}$ \\
\hline $\begin{array}{l}\text { Daniele Rugani } \\
\text { @DanieleRugani } \\
12 \text { March } \\
\text { Italian and } \\
\text { Juventus Football } \\
\text { Club star. }\end{array}$ & 118,000 & $\begin{array}{l}\text {... I want to reassure all } \\
\text { those who are worry- } \\
\text { ing about me, I'm fine. } \\
\text { I urge everyone to re- } \\
\text { spect the rules because } \\
\text { the virus makes no dis- } \\
\text { tinctions! }\end{array}$ & 6,472 & 19,700 & 84,900 & $\begin{array}{l}\text { No } \\
\text { video }\end{array}$ \\
\hline $\begin{array}{|lr|}\text { Idris Elba } & \\
\text { @idriselba } & \\
16 \text { March } & \\
\text { English rractor, } \\
\text { writer, producer, } \\
\text { rapper, } r \text { singer, } \\
\text { songwriter r and } \\
\text { disk jockey. }\end{array}$ & $2.9 \mathrm{~m}$ & $\begin{array}{l}\text { (Video and caption). } \\
\text { This morning I tested } \\
\text { positive for COVID- } 19 \text {. } \\
\text { I feel ok, I have no } \\
\text { symptoms so far but I } \\
\text { have been isolated since } \\
\text { I found out my possible } \\
\text { exposure to the virus. } \\
\text { Stay home people and } \\
\text { be pragmatic. I will } \\
\text { keep you updated on } \\
\text { how I'm doing. No } \\
\text { panic. } \\
\text { Wash your hands and } \\
\text { practice social distance. }\end{array}$ & 48,700 & 307,000 & $1.3 \mathrm{~m}$ & $34.3 \mathrm{~m}$ \\
\hline $\begin{array}{l}\text { BenMacAdams } \\
\text { @RepBenMcAdams } \\
\text { 19 March } \\
\text { American Attor- } \\
\text { ney and politician } \\
\text { serving as the U.S. } \\
\text { Representative for } \\
\text { Utah's congres- } \\
\text { sional district since } \\
\text { 2019. }\end{array}$ & 16,300 & $\begin{array}{l}\text {...I developed mild } \\
\text { symptoms. ... I imme- } \\
\text { diately isolated myself } \\
\text { in my home. My symp- } \\
\text { toms got worse and I } \\
\text { developed a fever, dry } \\
\text { cough and laboured } \\
\text { breathing. Today I } \\
\text { learned I tested positive. } \\
\text { I urge Utahns to take } \\
\text { this seriously and follow } \\
\text { heath recommendations } \\
\text { we're getting from the } \\
\text { CDC and other health } \\
\text { experts. }\end{array}$ & 771 & 1,706 & 4,400 & $\begin{array}{l}\text { No } \\
\text { video }\end{array}$ \\
\hline $\begin{array}{l}\text { Marcus Smart } \\
\text { @smart_MS3 } \\
\text { 19 March } \\
\text { American profes- } \\
\text { sional basketball } \\
\text { player. }\end{array}$ & 257,000 & $\begin{array}{l}\text { I was tested } 5 \text { days } \\
\text { ago and the res- } \\
\text { ults came positive. } \\
\text { I have been self- } \\
\text { quarantined... COVID- } \\
19 \text { must be taken with } \\
\text { the highest seriousness. }\end{array}$ & 3,510 & 19,600 & 113,000 & $4,1 \mathrm{~m}$ \\
\hline
\end{tabular}


Table 1. Continued from the previous page.

\begin{tabular}{|c|c|c|c|c|c|c|}
\hline $\begin{array}{c}\text { Celebrity } \\
\text { account }\end{array}$ & $\begin{array}{l}\text { No. of } \\
\text { followers }\end{array}$ & Tweet & $\begin{array}{l}\text { No. of } \\
\text { comments }\end{array}$ & $\begin{array}{l}\text { No. of } \\
\text { retweets }\end{array}$ & $\begin{array}{l}\text { No. of } \\
\text { likes }\end{array}$ & $\begin{array}{l}\text { No. of } \\
\text { views }\end{array}$ \\
\hline $\begin{array}{l}\text { Linda Lusardi } \\
\text { @lusardiofficial } \\
19 \text { March } \\
\text { English act- } \\
\text { ress, television } \\
\text { presenter and } \\
\text { former glamour } \\
\text { model. }\end{array}$ & 42,900 & $\begin{array}{l}\text { I want to thank you all } \\
\text { for your good wishes. } \\
\text { Sam and I have had } \\
\text { COVID-19 and are in } \\
\text { isolation so we do not } \\
\text { spread it to anyone else. }\end{array}$ & 457 & 240 & 3,544 & $\begin{array}{l}\text { No } \\
\text { video }\end{array}$ \\
\hline $\begin{array}{l}\text { Senator Randal } \\
\text { Paul } \\
\text { @RandPaul } \\
\text { 22 March } \\
\text { American politi- } \\
\text { cian serving as } \\
\text { U.S. Senator from } \\
\text { Kentucky. }\end{array}$ & $2,8 \mathrm{~m}$ & $\begin{array}{l}\text { Senator Rand Paul } \\
\text { has tested positive for } \\
\text { COVID-19. He is feeling } \\
\text { fine and is in quarant- } \\
\text { ine. He is asymptomatic } \\
\text { and was tested out of } \\
\text { abundance of caution } \\
\text { due to his extensive } \\
\text { travel and events. }\end{array}$ & 26,100 & 19,400 & 66,000 & $\begin{array}{l}\text { No } \\
\text { video }\end{array}$ \\
\hline $\begin{array}{l}\text { Marouane Fellaini } \\
\text { @fellaini } \\
\text { Moroccan-Belgian } \\
\text { football star. }\end{array}$ & $2,3 \mathrm{~m}$ & $\begin{array}{l}\text {...I have tested for } \\
\text { coronavirus and my test } \\
\text { result is positive... I will } \\
\text { follow the treatment } \\
\text { and hope to return to } \\
\text { the game as soon as pos- } \\
\text { sible. Please everyone } \\
\text { stay safe. }\end{array}$ & 4,872 & 17,100 & 83,900 & $\begin{array}{l}\text { No } \\
\text { video }\end{array}$ \\
\hline $\begin{array}{l}\text { Jason Collins } \\
\text { @jasoncollins } 98 \\
24 \text { March } \\
\text { American former } \\
\text { professional bas- } \\
\text { ketball player. }\end{array}$ & 97,200 & $\begin{array}{l}\text { I tested positive for } \\
\text { COVID-19. I had my } \\
\text { first symptoms on Wed } \\
\text { Mar 11. Terrible head- } \\
\text { ache. A few days later } \\
\text { I had a fever and then } \\
\text { the cough. Please stay } \\
\text { safe and continue to } \\
\text { social distance... Please } \\
\text { let's try to flatten the } \\
\text { curve... }\end{array}$ & 668 & 2,492 & 12,700 & $\begin{array}{l}\text { No } \\
\text { video }\end{array}$ \\
\hline $\begin{array}{l}\text { Boris Johnson } \\
\text { @BorisJohnson } \\
27 \text { March } \\
\text { Prime Minister of } \\
\text { the United King- } \\
\text { dom. }\end{array}$ & $2,7 \mathrm{~m}$ & $\begin{array}{l}\text { Over the last } 24 \text { hours } \\
\text { I have developed } \\
\text { mild symptoms and } \\
\text { tested positive for } \\
\text { coronavirus. I am now } \\
\text { self-isolating... We will } \\
\text { get through it by follow- } \\
\text { ing the health measures } \\
\text { we have heard so much } \\
\text { about. }\end{array}$ & 58,100 & 130,000 & 380000 & $23,9 \mathrm{~m}$ \\
\hline $\begin{array}{l}\text { Patrick McEnroe } \\
\text { @PatrickMcEnroe } \\
31 \text { March } \\
\text { American former } \\
\text { professional ten- } \\
\text { nis player and } \\
\text { broadcaster. }\end{array}$ & 147,000 & $\begin{array}{l}\text { Had minor symptoms } \\
\text { and my tests came posit- } \\
\text { ive...good news is I feel } \\
\text { fine. Let's get this thing, } \\
\text { let's nail this thing... We } \\
\text { got to stay home... }\end{array}$ & 556 & 671 & 5,992 & 548,000 \\
\hline
\end{tabular}

Continued on the next page. 
Table 1. Continued from the previous page.

\begin{tabular}{|c|c|c|c|c|c|c|}
\hline $\begin{array}{c}\text { Celebrity } \\
\text { account }\end{array}$ & \begin{tabular}{l|}
$\begin{array}{l}\text { No. of } \\
\text { followers }\end{array}$ \\
\end{tabular} & Tweet & \begin{tabular}{|l|l}
$\begin{array}{l}\text { No. of } \\
\text { comments }\end{array}$ \\
\end{tabular} & $\begin{array}{l}\begin{array}{l}\text { No. of } \\
\text { retweets }\end{array} \\
\end{array}$ & $\begin{array}{l}\text { No. of } \\
\text { likes }\end{array}$ & $\begin{array}{l}\text { No. of } \\
\text { views }\end{array}$ \\
\hline $\begin{array}{l}\text { Christopher } \\
\text { Cuomo } \\
\text { @ChrisCuomo } \\
21 \text { April } \\
\text { American televi- } \\
\text { sion journalist. }\end{array}$ & $1,7 \mathrm{~m}$ & $\begin{array}{l}\text { (Retweeted CNN in- } \\
\text { terview with caption). } \\
\text { Here's the moment } \\
\text { @ChrisCuomo emerged } \\
\text { out of the basement } \\
\text { where he's been riding } \\
\text { out coronavirus for the } \\
\text { last several weeks. I } \\
\text { could breath and felt } \\
\text { exhausted... }\end{array}$ & 13,400 & 3,000 & 241,000 & $2,4 \mathrm{~m}$ \\
\hline $\begin{array}{l}\text { Amr Waked } \\
\text { @amrwaked } \\
11 \text { June } 2020 \\
\text { Egyptian film, tele- } \\
\text { vision and stage } \\
\text { actor. }\end{array}$ & $7,1 \mathrm{~m}$ & $\begin{array}{l}\text { Thanks to God, my } \\
\text { son was cured of } \\
\text { Coronavirus. I will } \\
\text { work for you soon. I } \\
\text { will talk about my infec- } \\
\text { tion with the virus... I } \\
\text { took paracetamol- } \\
\text { Vitamin C, Thyme oil } \\
\text { pills-Krill oil pills, } 4 \text { raw } \\
\text { garlic cloves, one on } \\
\text { an empty stomach (you } \\
\text { can take garlic from the } \\
\text { pharmacy) , Ikenacia, } \\
\text { soothing cough and } \\
\text { thyme drink with lemon } \\
\text { and honey. }\end{array}$ & 162 & 181 & 1,870 & $\begin{array}{l}\text { No } \\
\text { video }\end{array}$ \\
\hline $\begin{array}{l}\text { Kiernan Forbes } \\
\text { (AKA) } \\
\text { @akaworldwide } \\
\text { 10 July } \\
\text { South African } \\
\text { multi-award win- } \\
\text { ning musician. }\end{array}$ & $4,5 \mathrm{~m}$ & $\begin{array}{l}\text { (Retweeted a press } \\
\text { statement). } \\
\text { award-winning South } \\
\text { African musician, AKA, } \\
\text { has tested positive for } \\
\text { the novel COVID-19 } \\
\text { virus. In an attempt to } \\
\text { create awareness and } \\
\text { to caution citizens to } \\
\text { be more careful in their } \\
\text { daily interactions with } \\
\text { others, AKA has chosen } \\
\text { to make his results } \\
\text { public. } \\
\text { As soon as you feel that } \\
\text { cough coming on, that } \\
\text { headache... weakness in } \\
\text { your muscles, chills at } \\
\text { night, trust me. Go test } \\
\text { ASAP. }\end{array}$ & 1,027 & 2,178 & 9,691 & $\begin{array}{l}\text { No } \\
\text { video }\end{array}$ \\
\hline $\begin{array}{l}\text { Amitabh Bachchan } \\
\text { @SrBachchan } \\
11 \text { July film actor, } \\
\text { Indian film producer } \\
\text { film and television } \\
\text { and producer. }\end{array}$ & $43,7 \mathrm{~m}$ & $\begin{array}{l}\text { I have tested positive } \\
\text { for COVID-19... shifted } \\
\text { hospital...family and } \\
\text { staff undergone tests... } \\
\text { All that have been } \\
\text { in close proximity to } \\
\text { me in the last } 10 \text { days } \\
\text { are requested to get } \\
\text { themselves tested! }\end{array}$ & 169,000 & 125,000 & 206,000 & $\begin{array}{l}\text { No } \\
\text { video }\end{array}$ \\
\hline
\end{tabular}


In U.S.A. and Africa, misinformation that people of black race were immune to COVID-19 infection went viral on both digital and offline spaces. The first black American celebrity to announce COVID-19 infection on social media was Idris Elba. Idris Elba's tweet confirmed that black people are not immune to COVID-19. He posted a video informing his followers that he had tested positive to COVID-19 and called on people to be 'pragmatic' about the reality of the pandemic. Following his initial tweet, Elba announced that his wife, Sabrina was also at risk, and both would go for self-isolation in different rooms. His message can be understood as a call for people to realise that COVID-19 is not racially selective considering that he was the first black celebrity to come out to announce his infection. Other COVID-19 positive black celebrities who took to twitter are American professional basketball player, Marcus Smart and Jason Collins, a former American professional basketball player. Both celebrities alluded to testing positive for the virus but Jason Collins went further to indicate that he experienced COVID-19 symptoms, 'fever and then the cough.' The rise of death among black individuals in countries like the United States prove that black people are not immune to the new Coronavirus and not only Idris Elba's infection confirms blacks are susceptible to the disease. Despite reports of increase in COVID-19 infections, some Africans still believed that they had some form of immunity to the coronavirus [NOIPolls, 2020]. South African music celebrity, Kiernan Forbes (AKA) announced he had tested positive for COVID-19 in a press statement he shared on his Twitter account. Coming at a time when South Africa was overwhelmed with a surge in COVID-19 infections and deaths, the main thrust of AKA's tweet was to 'create awareness' among his followers, not only in South Africa but even beyond that black Africans were not immune to the global health pandemic. Like several other South African celebrities who announced their COVID-19 infection, AKA's tweet, as medical experts argue, had a potential to dispel the rumour that COVID-19 is a Eurocentric disease [Makatile, 2020].

Another wave of disinfodemic was that COVID-19 is a disease that targets the lower classes in society. Contrary to this claim, some celebrities announced they had tested positive for COVID-19. British Prime minister Boris Johnson announced on his Twitter handle that he had tested positive for COVID-19. In the video, he confirmed having 'mild symptoms' and 'self-isolating', making his persona as ordinary as any other human being and equally vulnerable to the pandemic. American politicians, Senator Rand Paul and Ben McAdams also opened up to the COVID-19 infections on Twitter. What is interesting to note in their tweets is the different traits of COVID-19 infection. For Senator Rand Paul, he was 'feeling fine' and 'asymptomatic' while for Ben McAdams, his condition was characterised by 'a fever, dry cough and laboured breathing.' Announcing his infection on Twitter, Italian and Juventus Football Club star, Daniele Rugani was more specific, advising that 'the virus makes no distinctions', thus discrediting the claim that coronavirus targeted certain groups in society. Egyptian celebrity, Amr Waked only announced his coronavirus infection after he and his son had been successfully treated, promising to talk about his infection with the virus later. The central message in his tweet was that COVID-19 targets anyone regardless of class, even children. This study concludes that the appropriation of Twitter by celebrities to announce their infection and experiences with the pandemic was a way of challenging COVID-19 disinfodemic in line with Cohen [2020]'s argument that these announcements have a potential to make people aware of the magnitude of the pandemic. 
Celebrities amplified approved health guidelines to reduce the spread of COVID-19 popularised as 'flattening the curve'. Thunström et al. [2020] define flattening the curve to mean saving lives by reducing the pace and extent of COVID-19 infections. Actors Idris Elba, Tom Hanks, Boris Johnson and Linda Lusardi generated widespread engagement when they tweeted they had tested positive for COVID-19. Central to their message was the appeal for people to practice WHO-prescribed health guidelines for those already infected and those who are not. Tom Hanks announced that he and his wife had begun following 'health protocols' and 'self-isolating.' Idris Elba pleaded with his followers to 'stay at home', 'wash your hands and practice social distancing.' The video attracted $34.3 \mathrm{~m}$ views. British Prime Minister, Boris Johnson, probably cautious not to end up misinforming his followers, avoided mentioning specific measures to flatten the curve but called on public to follow 'health measures we've heard so much about.' The tweet attracted 23.9 million views. Linda Lusardi is one of the first women celebrities to publicly announce their COVID-19 infection. She told her followers that herself and her husband, Sam had tested positive to the virus and were 'in isolation so we do not spread it to anyone else.' Her message underscored the importance of self-isolation when one is infected as a way to reduce the spread of the coronavirus. This study establishes that celebrities took advantage of the persuasive power of their popularity to amplify official health information.

\section{How did celebrity tweets address fear of COVID-19?}

During the early stages of the pandemic, one of the major challenges posed by COVID-19 disinfodemic has been the creation of fear of the pandemic. As Mertens et al. [2020] note, fear could have a negative impact, particularly on the welfare of COVID-19 patients who became vulnerable to stigma both within their families and the wider society. This study establishes that the tone in most of the celebrity tweets acknowledged that COVID-19 was a reality but indicated that the virus could be treated. Upon testing positive, Moroccan-Belgian football star, Marouane Fellaini announced he had tested positive for COVID-19 but went on to assure his followers that the disease could be defeated as he said, 'I will follow the treatment and hope to return to the game as soon as possible.' What is interesting to note in his message is the attempt to diffuse fear of death arising from the fact that COVID-19 had no known cure yet. The announcement that he was undergoing 'treatment and being optimistic to return to sport 'soon' could assure his followers that available medications were helpful in treating the virus. CNN news anchor, Chris Cuomo retweeted CNN interview as he emerged out of quarantine where he had 'been riding out coronavirus'. The image of him, emerging out of quarantine and his 'riding out' the pandemic, ushers in an aura of hope as contrasted to the fear-laden news that had been circulating online. Patrick McEnroe told his followers that after testing positive, 'he was fine' and encouraged everyone to be part of the movement to defeat the pandemic. Amr Waked's announcement was different from other celebrities in the sense that he made it after he had recovered, and 'his son was cured of the virus.' As Neubauer, Witkop and Varpio [2019] opined, humans are unique in their ability to learn from the experiences of others. Therefore, Waked's announcement was likely to make people believe that COVID-19 could be treated, thus dispelling fear associated with it. At a time when 
the world was grappling with increasing cases of COVID-19, celebrities attempted to dispel fear and anxiety caused by the pandemic through their lived experiences and expression of optimism on getting cured from the virus.

\section{Conclusion}

\section{References}

AMP Research Lab (19th August 2020). The color of Coronavirus: COVID-19 deaths by race and ethnicity in the U.S.

URL: https: //www . apmresearchlab .org/covid/deaths-by-race.

Anger, I. and Kittl, C. (2011). 'Measuring influence on Twitter'. In: $11^{\text {th }}$ conference paper on knowledge management and knowledge technologies, pp. 1-4. URL: https: //www.hlt.inesc-id.pt/ fmmb/wiki/uploads/Work/misnis.ref07.pdf.

Banerjee, P. (27th April 2020). 'COVID-19 misinformation curve shows no signs of flattening'. Livemint.

URL: https://www. livemint.com/news/india/covid-19-misinformation-cur ve-shows-no-signs-of-flattening-11587888207849.html.

Bearak, M. (9th June 2020). 'Burundi's president, Pierre Nkurunzinza, dies of heart attack, government says'. The Washington Post. URL: https://www . washingtonp ost.com/world/africa/pierre-nkurunziza-burundi-president-dies/2020 /06/09/8cb62d9a-aa5e-11ea-a43b-be9f6494a87d_story.html.

Biran, O., Rosenthal, S., Andreas, J., McKeown, K. and Rambow, O. (2012). 'Detecting influencers in written online conversations'. In: Proceedings of the 2012 Workshop on Language in Social Media (LSM 2012) (Montreal, QC, Canada, 7th June 2012). Association for computational Linguistics, pp. 37-45. URL: https://www . aclweb . org/anthology/W12-2105/.

Brennen, J. S., Simon, F., Howard, P. and Nielsen, R. K. (7th April 2020). 'Types, sources and claims of COVID-19 misinformation'. Reuters Institute for the Study of Journalism. URL: https://reutersinstitute.politics.ox.ac.uk/types-sou rces-and-claims-covid-19-misinformation. 
Bruns, A., Highfield, T. and Lind, R. A. (2012). 'Blogs, Twitter and breaking news: the produsage of citizen journalism'. In: Produsing theory in a digital world: the intersection of audiences and production in contemporary theory. Ed. by R. A. Lind. Vol. 80. Bern, Switzerland: Peter Lang Publishing, pp. 15-32.

Chris, L. (2020). 'Is siekte'n straf van God? Teologiese perspektiewe uit die Bybel en die Apokriewe'. Litnet Akademies: 'n Joernaal vir die Geesteswetenskappe, Natuurwetenskappe, Regte en Godsdienswetenskappe 17 (1), pp. 343-371.

URL: https://www.litnet.co.za/is-siekte-n-straf-van-god-teologiese-p erspektiewe-uit-die-bybel-en-die-apokriewe/.

Claywell, C. (2016). What is social network theory? URL: http: //socialnetworking. I ovetoknow.com/What_is_Social_Network_Theory.

Clement, T. J. (2020). Global social networks ranked by number of users 2020. URL: https://www.statista.com/statistics/272014/global-social-networ ks-ranked-by-number-of-users.

Depoux, A., Martin, S., Karafillakis, E., Preet, R., Wilder-Smith, A. and Larson, H. (2020). "The pandemic of social media panic travels faster than the COVID-19 outbreak'. Journal of Travel Medicine 27 (3), taaa031. https://doi.org/10.1093/jtm/taaa031.

Donmez, A. E. (16th June 2020). 'Burundi's president died from COVID-19: reports. Country's presidency says Pierre Nkurunzinza died of heart failure'. Anadolu Agency. URL: https://www . aa.com.tr/en/africa/burundis-president-diedfrom-covid-19-reports/1878252.

Essoungou, A. (December 2010). 'A social media boom begins in Africa. Using mobile phones, Africans join the global conversation'. Africa Renewal. URL: https://www . un .org/africarenewal/magazine/december-2010/socialmedia-boom-begins-africa.

Granovetter, M. S. (1973). 'The strength of weak ties'. American Journal of Sociology 78 (6), pp. 1360-1380. https://doi.org/10.1086/225469.

Heldman, A. B., Schindelar, J. and Weaver, J. B. (2013). 'Social media engagement and public health communication: implications for public health organizations being truly 'social'. Public Health Reviews 35 (1), pp. 1-18. https://doi.org/10.1007/bf03391698.

Jin, F., Wang, W., Zhao, L., Dougherty, E., Cao, Y., Lu, C.-T. and Ramakrishnan, N. (2014). 'Misinformation propagation in the age of Twitter: a quantitative analysis of tweets during the Ebola crisis reveals that lies, half-truths and rumors can spread just like true news'. IEEE Computer Society 47 (12), pp. 90-94. https://doi.org/10.1109/mc.2014.361.

Kadushin, C. (2004). 'Some basic network concepts and propositions'. In: Introduction to social network theory. Ed. by C. Kadushin. Boston, MA, U.S.A.

- (2012). Understanding social networks: theories, concepts and findings. New York, NY, U.S.A.: Oxford University Press.

Khamis, S., Ang, L. and Welling, R. (2017). 'Self-branding, 'micro-celebrity' and the rise of social media influencers'. Celebrity Studies 8 (2), pp. 191-208. https://doi.org/10.1080/19392397.2016.1218292.

Korda, H. and Itani, Z. (2013). 'Harnessing social media for health promotion and behavior change'. Health Promotion Practice 14 (1), pp. 15-23. https://doi.org/10.1177/1524839911405850.

Kuckartz, U. (2014). Qualitative text analysis: a guide to methods, practice and using software. London, U.K.: Sage. 
Leung, V. S. Y. and Cheng, K. (2016). 'Public's perception of celebrities with serious illness in Hong Kong and the impact of media stories of ill celebrities on health awareness and behaviour'. Journal of Communication in Healthcare 9 (4), pp. 256-266. https://doi.org/10.1080/17538068.2016.1247128.

Liang, H., Fung, I. C.-H., Tse, Z. T. H., Yin, J., Chan, C.-H., Pechta, L. E., Smith, B. J., Marquez-Lameda, R. D., Meltzer, M. I., Lubell, K. M. and Fu, K.-W. (2019). 'How did Ebola information spread on Twitter: broadcasting or viral spreading?' BMC Public Health 19 (1), 438. https : / doi .org/10 .1186/s12889-019-6747-8.

Linneberg, M. S. and Korsgaard, S. (2019). 'Coding qualitative data: a synthesis guiding the novice'. Qualitative Research Journal 19 (3), pp. 259-270. https://doi.org/10.1108/qrj-12-2018-0012.

Makatile, D. (29th March 2020). 'Medical experts slam claims that black people are immune to coronavirus'. IOL.

URL: https://www.iol.co.za/news/south-africa/gauteng/medical-experts -slam-claims-that-black-people-are-immune-to-coronavirus-45735869.

Mare, A. (2018). 'Politics unusual? Facebook and political campaigning during the 2013 harmonised elections in Zimbabwe'. African Journalism Studies 39 (1), pp. 90-110. https://doi.org/10.1080/23743670.2018.1425150.

Mare, A. and Matsilele, T. (2020). 'Hybrid media system and the July 2018 elections in "post-Mugabe" Zimbabwe'. In: Social media and elections in Africa. Ed. by M. Ndlela and W. Mano. Vol. 1. Cham, Switzerland: Palgrave Macmillan, pp. 147-176. https://doi.org/10.1007/978-3-030-30553-6_8.

Medelyan, A. (10th October 2019). Coding qualitative data: how to code qualitative research.

URL: https://getthematic.com/insights/coding-qualitative-data.

Mertens, G., Gerritsen, L., Duijndam, S., Salemink, E. and Engelhard, I. M. (2020). 'Fear of the coronavirus (COVID-19): predictors in an online study conducted in March 2020'. Journal of Anxiety Disorders 74, p. 102258. https://doi.org/10.1016/j.janxdis.2020.102258.

Montoya, P. and Vandehey, T. (2009). The brand called you. Create a personal branding that wins attention and grows your business. London, U.K.: McGraw-Hill.

Mutsvairo, B. and Bebawi, S. (2019). 'Journalism educators, regulatory realities and pedagogical predicaments of the "fake news" era: a comparative perspective on the Middle East and Africa'. Journalism E Mass Communication Educator 74 (2), pp. 143-157. https://doi.org/10.1177/1077695819833552.

Neiger, B. L., Thackeray, R., Burton, S. H., Giraud-Carrier, C. G. and Fagen, M. C. (2013). 'Evaluating social media's capacity to develop engaged audiences in health promotion settings'. Health Promotion Practice 14 (2), pp. 157-162. https://doi.org/10.1177/1524839912469378.

Neubauer, B. E., Witkop, C. T. and Varpio, L. (2019). 'How phenomenology can help us learn from the experiences of others'. Perspectives on Medical Education 8 (2), pp. 90-97. https://doi.org/10.1007/s40037-019-0509-2.

Newman, E., Dawel, A., Jalbert, M. C. and Schwarz, N. (26th May 2020). 'Seeing is believing: how media myth-busting can actually make false beliefs stronger'. The Conversation.

URL: https://theconversation.com/seeing-is-believing-how-media-mythb usting-can-actually-make-false-beliefs-stronger- 138515.

Ngewa, R. N. and Kuriansky, J. (2016). 'Awareness and education about Ebola through public health campaigns'. In: The psychosocial aspects of a deadly epidemic: what Ebola has taught us about holistic healing. Ed. by J. Kuriansky. Santa Barbara, CA, U.S.A.: ABC-CLIO/Praeger, p. 335. 
NOIPolls (14th April 2020). COVID-19 poll results release.

URL: https://noi-polls.com/covid-19-poll-result-release-2.

Nouri, M. (2018). 'The power of influence: traditional celebrity vs. social media influencer'. Pop culture intersections 32.

URL: https://scholarcommons.scu.edu/engl_176/32.

Odlum, M. and Yoon, S. (2015). 'What can we learn about the Ebola outbreak from tweets?' American Journal of Infection Control 43 (6), pp. 563-571.

https://doi.org/10.1016/j.ajic.2015.02.023.

Oyeyemi, S. O., Gabarron, E. and Wynn, R. (2014). 'Ebola, Twitter and misinformation: a dangerous combination?' BMJ 349, g6178-g6178. https://doi.org/10.1136/bmj.g6178.

Pataraia, N., Falconer, I., Margaryan, A., Littlejohn, A. and Fincher, S. (2014). “Who do you talk about your teaching?': networking activities among university teachers'. Frontline Learning Research 2 (2), pp. 4-14.

https://doi.org/10.14786/flr.v2i2.89.

Posetti, J. and Bontcheva, K. (2020). DISINFORDEMIC: dissecting responses to COVID-19 disinformation. UNESCO Policy Brief 2.

URL: https://en. unesco.org/covid19/disinfodemic/brief2.

Qazvinian, V., Rosengren, E., R., R. D. and Mei, Q. (2011). 'Rumor has it: identifying misinformation in microblogs'. In: Proceedings of the 2011 Conference on Empirical Methods in Natural Language Processing (Edinburgh, Scotland, U.K.

27th-31st July 2011). Association for Computational Linguistics, pp. 1589-1599. URL: https://www . aclweb .org/anthology/D11-1147.

Rettberg, W. J. (2017). 'Self-representation in social media'. In: The Sage handbook of social media. Ed. by J. W. Burgess, M. A. and T. Poell. London, U.K.: Sage, pp. 429-443. URL: http: //hdl . handle. net/1956/13073.

Rojek, C. (2001). Celebrity. London, U.K.: Reaktion Books Ltd.

Roller, M. R. and Lavrakas, P. J. (2015). Applied qualitative research design: a total quality framework approach. New York, NY, U.S.A.: Guilford Press.

Rueda, A. M. and Helfrich, U. (2014). 'La crisis en 140 caracteres: el discurso propagandístico en la red social Twitter'. Cultura, Lenguaje y Representación 12, pp. 59-86.

URL: http://www.e-revistes.uji.es/index.php/clr/article/view/1385.

Salek, T. A. and Cole, A. W. (2018). 'Donald Trump tweets the 2014 Ebola outbreak: the infectious nature of apocalyptic counterpublic rhetoric and constitution of an exaggerated health crisis'. Communication Quarterly 67 (1), pp. 21-40. https://doi.org/10.1080/01463373.2018.1526812.

Scott, J. (2000). Social Network Analysis: A Handbook. Thousand Oaks, CA, U.S.A.: SAGE Publications.

Scott, K. and Wray, M. (23rd March 2020). 'Celebrities and public figures who've tested positive for coronavirus'. Global news. URL: https://globalnews.ca/news/6717200/celebrities-coronavirus.

Sonke, J. and Pesata, V. (2015). 'The arts and health messaging: exploring the evidence and lessons from the 2014 Ebola outbreak'. BMJ Outcomes 1, pp. 36-41.

Stever, G. S. and Lawson, K. (2013). 'Twitter as a way to communicate with fans: implications for parasocial interaction'. North American Journal of Psychology 15 (2), pp. 339-354.

Thunström, L., Newbold, S. C., Finnoff, D., Ashworth, M. and Shogren, J. F. (2020). 'The benefits and costs of using social distancing to flatten the curve for COVID-19'. Journal of Benefit-Cost Analysis 11 (2), pp. 179-195.

https://doi.org/10.1017/bca.2020.12. 
Tran, T. and Lee, K. (2016). 'Understanding citizen reactions and Ebola-related information propagation on social media'. In: 2016 IEEE/ACM International Conference on Advances in Social Networks Analysis and Mining (ASONAM) (San Francisco, CA, U.S.A. 18th-21st August 2016). IEEE. https://doi.org/10.1109/asonam.2016.7752221.

Vulture (9th August 2020). 'All celebrities who have tested positive for the coronavirus'. Vulture. URL: https://www . vulture.com/article/famous-people - celebrities-with-coronavirus .html.

Waisbord, S. (2020). 'Fake health news in the new regime of truth and (mis)information'. Revista Eletrônica de Comunicação, Informação e Inovação em Saúde 14 (1), pp. 6-11. https: //doi.org/10.29397/reciis.v14i1.1953.

West Virginia University (19th March 2020). 'Celebrities, athletes and public figures with COVID-19 influence public perception of the virus'. News Wise.

URL: https://www. newswise.com/coronavirus/celebrities-athletes-and-p ublic-figures-with-covid-19-influence-public-perception-of-the-viru s/?article_id $=728479$.

World Health Organization (2015). Ebola virus disease. URL: http://www. who.int/mediacentre/factsheets/fs103/en/.

- (2020). Coronavirus disease 2019 (COVID-19). Situation report 94. URL: https://www. who.int/docs/default-source/coronaviruse/situationreports/20200423-sitrep-94-covid-19.pdf.

Worldometer (2020). Countries where COVID-19 has spread. URL: https : / www . world ometers .info/coronavirus/countries-where-coronavirus-has-spread.

Zak, S. and Hasprova, M. (2020). 'The role of influencers in the consumer decision-making process'. SHS Web of Conferences 74, p. 03014. https://doi.org/10.1051/shsconf/20207403014.

Authors

\section{How to cite}

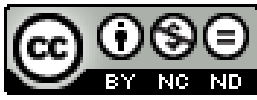

Wishes Mututwa researches on social media, political communication and popular culture. He holds a Ph.D. in Communication from University of Fort Hare. E-mail: wishesmtutwa@gmail.com.

Trust Matsilele lectures in journalism and public relations programmes at the Cape Peninsula University of Technology. He also acts as a postgraduate supervisor at Masters' level. He researches on dissident and protest cultures, social media and use of artificial intelligence in African newsrooms. He holds a D.Litt. et Phil Communication Studies from the University of Johannesburg and Masters Philosophy Journalism from Stellenbosch University.

E-mail: trust.matsilele@gmail.com.

Mututwa, W. T. and Matsilele, T. (2020). 'COVID-19 infections on international celebrities: self presentation and tweeting down pandemic awareness'. JCOM 19 (05), A09. https:/ / doi.org/10.22323/2.19050209. 